\title{
Infection by the microsporidium of Clado Nosema/Vairimorpha in pupal parasitoids
}

\author{
JOÃO P.P. PAES ${ }^{1}$, VANESSA R. CARVALHO ${ }^{2}$, AMANDA R. DE SOUZA ${ }^{3}$, \\ CARLOS F. WILCKEN ${ }^{3}$ and REGIANE C.O. F. BUENO ${ }^{1}$
}

\begin{abstract}
${ }^{1}$ Universidade Estadual Paulista Júlio de Mesquita Filho/ UNESP, Faculdade de Ciências Agronômicas, Grupo de Pesquisa em Manejo Integrado de Pragas na Agricultura, Rua Barbosa de Barros, 1780, 18610-307 Botucatu, SP, Brazil ${ }^{2}$ Universidade Estadual Paulista Júlio de Mesquita Filho/UNESP, Instituto de Biotecnologia, Laboratório de Genômica Funcional e Microbiologia de Vetores, Alameda das Tecomarias, s/n, 18607-440 Botucatu, SP, Brazil ${ }^{3}$ Universidade Estadual Paulista Júlio de Mesquita Filho/UNESP, Faculdade de Ciências Agronômicas, Laboratório de Controle Biológico de Pragas Florestais / LCBPF, Rua José Barbosa de Barros, 1780, 18610-307 Botucatu, SP, Brazil
\end{abstract}

Manuscript received on April 4, 2018; accepted for publication on October 2,2018

\begin{abstract}
How to cite: PAES JPP, CARVALHO VR, SOUZA AR, WILCKEN CF AND BUENO RCOF. 2019. Infection by the microsporidium of Clado Nosema/Vairimorpha in pupal parasitoids. An Acad Bras Cienc 91: e20180326. DOI. 10.1590/0001-3765201920180326.

Abstract: The sugarcane borer, Diatraea saccharalis is one of the hosts more used for parasitoid pupal multiplication in Brazil. The parasitoids pupal of Trichospilus diatraeae and Palmistichus elaeisis are generalist natural enemies with potential to suppress populations of diverse families of lepidopteran pests. The success in the utilization of these natural enemies in the field is directly related to the capacity of search of the host, this capacity might be affected by the presence of the pathogens. In this context, the aim of this essay was to detect the presence of intracellular parasites of Phylum Microsporidia. These pathogens may cause morphological and behavioral alterations. The presence of infection was verified by microscopy and was confirmed by amplification of region small subunit (SSU) of ribosomal RNA using universal primers for microsporidia of Nosema sp. The purified PCR products were submitted to sequencing, and the sequences that had been obtained were edited and aligned with the sequences in a Genbank database. In this way, it was possible to verify the presence of intracellular parasites in T. diatraeae, P. elaeisis and $D$. saccharalis pertaining to Clade Nosema/Vairimorpha. However, this is the first one report about detection of the microsporidia in the parasitoids T. diatraeae and P. elaeisis.
\end{abstract}

Key words: Biological control, microsporidium, pupal parasitoids, PCR.

\section{INTRODUCTION}

The parasitoids Trichospilus diatraeae (Cherian \& Margabandhu) and Palmistichus elaeisis (Delvare \& LaSalle) (Hymenoptera: Eulophidae) are natural enemies that can suppress populations of several families of lepidopteran pests of agricultural crops (Paron and Berti-Filho 2000) and forests (Pereira

Correspondence to: João Paulo Pereira Paes

E-mail: joaopauloppaes@hotmail.com

ORCid: https://orcid.org/0000-0002-3651-1166 et al. 2011). In order, these natural enemies are generalists and effectives in suppressing populations of pest insects, therefore, they have the potential to be used in biological control programs (Rodrigues et al. 2013, Paron and Berti-Filho 2000).

The effective use of natural enemies in inundative releases depends of the selection of a physiologically suitable alternative host for mass production (Vinson and Iwantch 1980). The host must have high nutritional quality and be produced 
easily, efficiently and economically (Parra et al. 2002). The sugarcane borer, Diatraea saccharalis (Fabricius) (Lepidoptera: Crambidae) its stands out as a nutritionally appropriate host for parasitoid multiplication (Rodrigues et al. 2013). However, the quality control of the mass production of parasitoids, $T$. diatraeae and $P$. elaeisis must always be verified, because the presence of pathogens in the hosts can interfere in the development of the parasitoids and consecutively in the action of pest control in the field.

The occurrence of microsporids in the populations of $D$. saccharalis (Simões et al. 2015) may become a problem in the mass production of T. diatraeae and P. elaeisis. These microsporids are obligate intracellular parasitic fungi (Corradi and Keeling 2009). The spores are metabolically inactive and, when ingested, germinate in the lumen of the insect's midgut, injecting the infectious apparatus, composed of a polar tube that penetrates the cell membrane and allows the sporoplasm to be transferred to the host (Bigliardi and Sacchi 2001). In the host cell, the microsporids explore the organism to multiply, using organelles and metabolite products as substrate to complete the cycle (Dean et al. 2016). After the multiplication, new resistance spores are formed and released through cell lysis and excreted in insect feces (Gisder et al. 2011).

The parasites exploit and frequently manipulate the host inducing morphological and behavioral changes to increase transmission success (Kurze et al. 2016a). Infected populations commonly show increased time to complete the larval and pupal stages (Simões et al. 2012, Kermani et al. 2014), reduction in longevity of adults (Simões et al. 2012), decrease in the rate of emergence and fertility (Kermani et al. 2014), behavioral modifications in host search (Simões et al. 2012, Kermani et al. 2014), abnormal adult abdomen size (Simões et al. 2015), stress (Kurze et al. 2016b). The disease caused by these pathogens, in addition to affecting biological aspects of insects, has become an economic problem (Aroee et al. 2017), for example in bee hives causes reduction of honey production (Higes et al. 2008) and colony collapse disorder (Huang et al. 2007).

However, it is extremely difficult to morphologically distinguish between microsporids species by light microscopy because the spores are very similar. Then, the recognition of the species using molecular markers might be very helpful in the diagnosis and identification of microsporids. Thus, it is necessary to use molecular diagnostic tools by the PCR technique, which provides a more accurate result for the detection of microsporidial infection, because it allows detection of the parasite even at very low levels of infection (Ansari et al. 2017).

In view of the importance of $T$. diatraeae and $P$. elaeisis in biological control programs applied to several pests of agricultural and forestry importance, the objective of this work was to verify the presence of microsporids belonging to the Clado Nosema/Vairimorpha in parasitoids $T$. diatraeae and P. elaeisis and the host D. saccharalis.

\section{MATERIALS AND METHODS}

\section{HOST AND PARASITOID REARING}

Larvae and pupal of the host D. saccharalis were obtained from mass rearing of biofactory. The parasitoids $T$. diatraeae and $P$. elaeisis and the host D. saccharalis were kept in stock at the Laboratório de Controle Biológico de Pragas Florestais (LCBPF) da Faculdade de Ciências Agronômicas da Universidade Estadual Paulista (FCA / UNESP). The identification of the parasitoids was confirmed by the taxonomist Dr. Valmir A. Costa, the specimen vouchers of the parasitoids were deposited in the Entomophagous Insects Collection "Oscar Monte", from the Biological Institute, based in Campinas, State of São Paulo, Brazil. The identification of the host was confirmed by Dr. Roberto Antonio 
Zucchi, the specimen vouchers were deposited in the Coleção Entomológica do Departamento de Proteção de Plantas da Faculdade de Ciências Agronômicas da Universidade Estadual Paulista (FCA / UNESP), Botucatu, Estado de São Paulo, Brazil. Pupal of D. saccharalis were transferred to polyvinyl chloride (PVC) cages $(20 \mathrm{~cm}$ diameter by $20 \mathrm{~cm}$ height), closed with fabric at the bottom and with voile tissue at the top. The interior of these cages was coated with sulphite paper as a substrate for oviposition. The collected eggs were sterilized with formaldehyde $(0.5 \%)$ and copper sulphate (17\%) and inoculated into glass tubes $(2 \mathrm{~cm} \times 8$ $\mathrm{cm})$ containing artificial diet proposed by King and Hartley (1985). From 4 until 7 larvae were placed in each tube until reaching third instar. In this phase, the larvae were fed with $1 \mathrm{~cm}^{3}$ of artificial diet and placed in a plastic container $(1.5 \mathrm{~cm} \times 5 \mathrm{~cm})$ until reaching the pupal stage (Fonseca et al. 2015). The parasitoids were reared in pupal of $D$. saccharalis aged 48 to 72 hours. Host pupal were offered to the parasitoids, which were packed in glass tubes $(2.5 \mathrm{~cm}$ in diameter and $8.5 \mathrm{~cm}$ long), sealed with voile-type tissue and fed with pure honey, for parasitism up to 72 hours. The insects were kept in an air-conditioned chamber at $25 \pm 2{ }^{\circ} \mathrm{C}$, relative humidity of $70 \pm 10 \%$ and a 12 -hour photophase until adult emergence that occurs around the 15th to the 18th day (Zaché et al. 2010).

\section{PREPARATION OF SMEARS}

Diatraea saccharalis larvae of third instar with an apparent symptom of microsporidia infection and adults of pupal parasitoids were used to make smears and identify spores of microsporids. The insects were killed by freezing and, later, a crosssection with scalpel was carried out in the abdomen of the same. The extravasation of the intestinal contents was placed on a glass slide and a drop of saline $(0.85 \% \mathrm{NaCl})$ added. Maceration of the larvae was performed on a microscopic slide and the excess body content of the insects was removed with forceps. The slides were fixed in methanol for ten minutes and then air dried. Spore staining was performed with $50 \%$ diluted Giemsa solution for 30 minutes. The slides were washed in tap water to remove excess dye and air dried. The smears were visualized with a phase contrast microscope on the 1000x objective (Zeiss Primo Star) (Alves et al. 1998).

\section{GENOMIC DNA EXTRACTION AND PCR}

Samples of $D$. saccharalis, $T$. diatraeae and $P$. elaeisis with confirmed identification were obtained from stock for evaluation of the presence of spores of Nosema spp., Palmistichus elaeisis and T. diatraeae adults and third instar larvae of $D$. saccharalis were stored in the freezer at $-20{ }^{\circ} \mathrm{C}$. After thawing, a caterpillar was randomly selected for genomic DNA extraction and standardization of the polymerase reaction in chain (PCR). The caterpillar was macerated and later the larger parts of the insect's body were removed $80 \mu \mathrm{l}$ of $10 \%$ Chelex solution and $8 \mu \mathrm{l}$ of $20 \mathrm{mg} / \mathrm{mL}$ proteinase $\mathrm{K}$ were added to the body contents in microtube and homogenized. Then the microtube containing the sample was placed in a thermal block at $95{ }^{\circ} \mathrm{C}$ for 20 minutes to release the DNA from the cells. Chelex protects DNA from the effects of heating used to release DNA from cells by sequestering divalent heavy metal ions from enzymes that could damage the structure of the molecule (Walsh 1991). The same procedure was used to extract parasitoids, however, a pool of 50 macerated and homogenized individuals was used with $80 \mu \mathrm{l}$ of $10 \%$ Chelex solution and $8 \mu \mathrm{l}$ of $20 \mathrm{mg}$ / $\mathrm{mL}$ proteinase $\mathrm{K}$ in microtube and then placed in a thermal block at $95^{\circ} \mathrm{C}$ for 20 minutes. The protocol for DNA extraction was performed using Chelex $100 ®$ resin (Coombs et al. 1999). Then, a mini-spin centrifugation was performed and the supernatants were collected for PCR. 
The small subunit (SSU) region of ribosomal RNA was amplified using universal primers for microspores of Nosema sp., (F) CACCAGGTTGATTCTGCT and (R) GTTACCCGTCACTGCCTTG, expected size of $222 \mathrm{bp}$ (Klee et al. 2006). The PCR reaction was prepared containing $12.5 \mu \mathrm{l}$ of Gotaq Hot Start (Promega), with the reagents required for the reaction: $5 \mathrm{U} / \mu \mathrm{l} \mathrm{Taq}, 100 \mu \mathrm{M}$ of each dNTP and $25 \mathrm{mM} \mathrm{MgCl}_{2}, 5 \mu \mathrm{l}$ of Nuclease Free Water (Promega), $1.25 \mu \mathrm{l}$ of each primer [10 $\mathrm{mM}]$ and $5 \mu \mathrm{l}$ of genomic DNA, totaling $25 \mu \mathrm{l}$ per reaction. The polymerase chain reaction (PCR) was carried out in thermal cycler (Infinigen, model TC-96CG) with initial denaturation for 4 minutes at $95{ }^{\circ} \mathrm{C}$, followed by 45 cycles with denaturation at $95{ }^{\circ} \mathrm{C}$ for 1 minute, followed by the annealing phase a 48 ${ }^{\circ} \mathrm{C}$ for 1 minute and extension at $72{ }^{\circ} \mathrm{C}$ for 1 minute and with a final polishing step for 4 minutes at 72 ${ }^{\circ} \mathrm{C}$ (Tay et al. 2005). The amplification products were visualized by $1 \%$ agarose gel electrophoresis, using a 100 bp marker (Norgen). The agarose gel was visualized and photographed in ultraviolet light transilluminator (Major Science).

\section{SEQUENCING}

Purifications of the PCR products were performed using the Norgen PCR Purification Kit (Qiagen, Cat \# 14400), following the manufacturer's recommendations. Sequencing by Sanger DNA automatic sequencer (Model: ABI 3500 - Applied Biosystems) was performed at the Institute of Biotechnology (IBTEC - UNESP). The nucleotide sequences of SSU rRNA for the microsporide isolates obtained from $D$. saccharalis and the pupal parasitoids were analyzed using the Geneious v. 9.1.5 and compared to the database (GenBank, http://www.ncbi.nlm.nih.gov) for the identification of genetic similarity.

The alignment was performed using the Geneious v. 9.1.5, with the sequences obtained in this study added from other sequences of microsporidia obtained in GenBank. Phylogenetic analysis was done using the program MrBayes 3.2.2 (Huelsenbeck and Ronquist 2001). Bayesian analysis was performed for 30 million generations with sampling every 1000 generations. Each analysis consisted of four independent runs, each using four coupled Markov chains. The convergence of the race was monitored by finding the plateau in the probability score (standard deviation of divided frequencies $<0.0015$ ). The first $25 \%$ of each run was discarded for the estimation of a consensus topology and later probability for each node.

\section{RESULTS AND DISCUSSION}

INFECTION BY THE MICROSPORIDIUM OF CLADO NOSEMA/VAIRIMORPHA IN PUPAL PARASITOIDS

Microspores infect vertebrates and invertebrates, including insects, fish and mammals (Weiss 2001, Morsy et al. 2013, Liu et al. 2015). The presence of these pathogens has been widely discussed due to the increase of infection in several hosts (Emsen et al. 2016), a fact resulting from the biological and behavioral changes caused by the parasite (Simões et al. 2012, Kermani et al. 2014, Kurze et al. 2016b).

In this study, oval-shaped spores, resistance structure of intracellular parasites of Clado Nosema/Vairimorpha were isolated from the intestinal contents of $D$. saccharalis larvae (Fig. 1). In the slides of the body contents of parasitoids T. diatraeae and P. elaeisis, some parasite spores were visualized, but they did not quantified. This is possibly due to the lower degree of infection of the pathogen in the parasitoids (Bjørnson 2008) and/or the stage of development of the microspore in the host cell (Becnel et al. 2002).

Microscopy is a cheap and routine technique for the identification of microsporids, however, it can be laborious and requires knowledge to detect the spores. In addition, the pathogen may be present in only a few individuals when the prevalence 


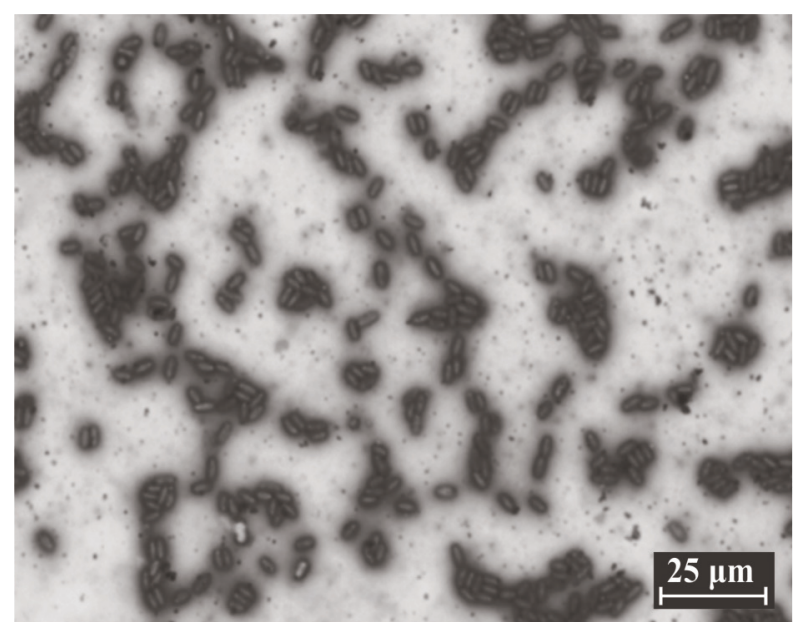

Figure 1 - Image of the smear stained with Giemsa. Spores of the Clado Nosema/Vairimorpha isolated from the intestinal contents of $D$. saccharalis viewed under a phase contrast microscope $(1000 \mathrm{x})$. Scale bar $=25 \mu \mathrm{m}$.

is low, a fact that makes it difficult to diagnose the infection (Bjørnson 2008). Although it is considered reliable for detection, it is not sufficient for a precise identification of these parasites, since the morphological structures of some pathogens are very similar, resulting in a high risk of errors in diagnosis (Ansari et al. 2017).

The PCR reaction revealed by amplification of ribosomal RNA from microsporids that the host populations of $D$. saccharalis and parasitoids $T$. diatraeae and P. elaeisis are infected by intracellular parasites. The SSR rRNA sequence has been widely used as a molecular marker to estimate phylogenetic relationships between microsporidia by having highly conserved gene. However, this gene can not be used to distinguish closely related species (Canning et al. 1999, Tsai et al. 2003).

The results suggest that the isolates are closely related to the species of Vairimorpha sp., with which it shares $100 \%$ identity of the SSU rRNA gene (222 bp) of these sequences in Nucleotide BLAST, and the species of the genus Vairimorpha forms a clade with Nosema spp. and Rugispora istanbulensis (Fig. 2). However, the genera Nosema and Vairimorpha can not be separated into different clades using molecular analyzes (Tsai et al. 2003, $\mathrm{Ku}$ et al. 2007).

The occurrence of microsporids in the populations of $D$. saccharalis and parasitoids $T$. diatraeae and P. elaeisis may become a problem in mass production and in biological control programs. Pathogens of this group can remain latent without causing visible symptoms in hosts (Bjørnson 2008). This can be perpetuated for several generations through the possibility of vertical transmission, when infection is transmitted from parents to offspring and horizontal when it occurs through contact between individuals, which may be favored by the confinement environment of mass productions (Dubuffet et al. 2013). Recent studies have shown a significant effect of the breeding laboratories' ambient temperature on the intensity of the endoparasites Nosema spp. in bees. Spores find temperatures reasonably regulated during their life stages inside the host, but when exposed to the outside temperature, they exhibit a differential sensitivity to temperatures during the transmission to new hosts (Gisder et al. 2017, Retschnig et al. 2017).

Parasitoids massively multiplied, are usually contaminated when the larvae feed on the hemolymph or infected tissues, resulting in a variety of changes (Simões et al. 2012). Depending on the degree of infection in populations of natural enemies, changes in the duration of the juvenile phase, reduced survival, altered flight behavior and host search may occur. These symptoms were reported in C. flavipes (Simões et al. 2012), Cotesia vertalis (Haliday) (Hymenoptera: Braconidae) (Kermani et al. 2014), Macrocentrus grandii Goidanich (Hymenoptera: Braconidae) (Andreadis 1982), Phytoseiulus persimilis (Acari: Phytoseiidae) (Bjørnson and Keddie 1999) and Chrysoperla carnea (Stephens) (Neuroptera: Chrysopidae) (Bjørnson et al. 2013). Thus, it is characterized the need for detailed investigation of the interaction between infection by this microsporid in hosts $D$. 


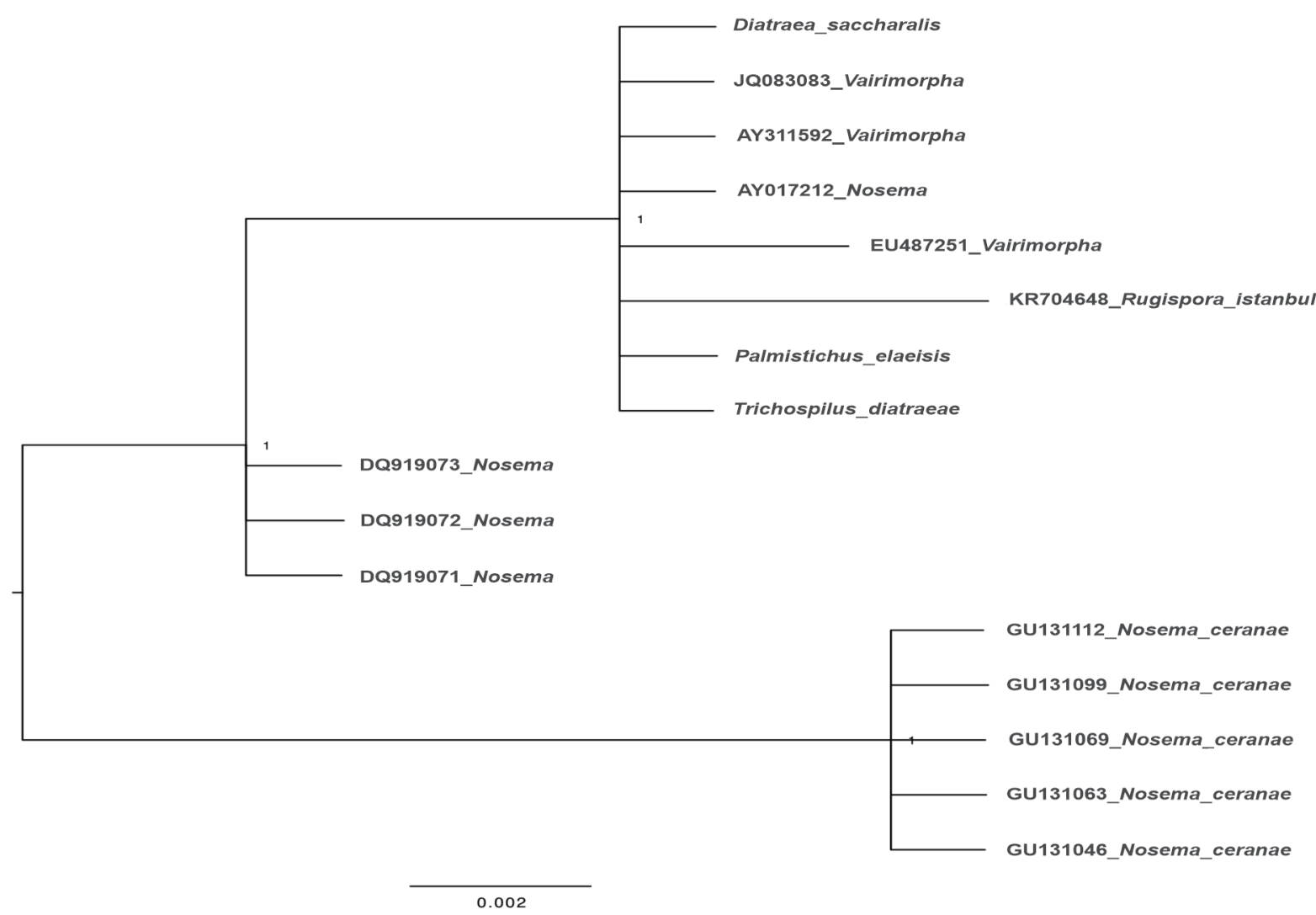

Figure 2 - Phylogenetic tree of the small subunit region (SSU) of ribosomal RNA from microsporidia isolated from $D$. saccharalis and from the parasitoid T. diatraeae and P. elaeisis.

saccharalis and pupal parasitoids, T. diatraeae and P. elaeisis, to verify the quality and improve the understanding of the real impact of this parasite in biology and in the search behavior of the host in the field.

\section{CONCLUSION}

We conclude that according to the morphological characteristics of the spores and molecular genetics, the presence of Clado Nosema/Vairimorpha microsporids in the pupal parasitoids T. diatraeae and P. elaeisis and in the host $D$. saccharalis was verified.

\section{ACKNOWLEDGMENTS}

To the taxonomist Dr. Valmir A. Costa from Instituto Biológico/APTA in Campinas, São Paulo State, Brazil by confirmation of the identification of the parasitoids. To the taxonomist Dr. Roberto Antonio
Zucchi by confirmation of the identification of the host of this manuscript.

To Programa Cooperativo sobre Proteção Florestal (PROTEF) of Instituto de Pesquisas e Estudos Florestais (IPEF) for financial support.

\section{AUTHOR CONTRIBUTIONS}

João Paulo P. Paes, Vanessa R. de Carvalho and Amanda R. de Souza performed the experiment, analysed and interpreted the data, and drafted the manuscript. Carlos F. Wilcken and Regiane C.O. de Freitas Bueno planned the proposal and supervised the experiment, interpreted the data and were responsible for the revision of the manuscript.

\section{REFERENCES}

ALVES SB, ALMEIDA JEM, MOINO JÚNIOR A AND ALVES LFA. 1998. Técnicas de laboratório. In: Alves SB 
(Ed), Controle Microbiano de Insetos. Piracicaba: Fealq, p. 637-712.

ANDREADIS TG. 1982. Impact of Nosema pyrausta on field populations of Macrocentrus grandii, an introduced parasite of the European corn borer, Ostrinia nubilalis. J Invertebr Pathol 39: 298-302.

ANSARI MJ, AL-GHAMDI A, ADGABA N, KHAN KA AND ALATTAL Y. 2017. Geographical distribution and molecular detection of Nosema ceranae from indigenous honey bees of Saudi Arabia. Saudi J Biol Sci 24: 83-991.

AROEE F, AZIZI H, SHIRAN B AND PIRALI KHEIRABADI K. 2017. Molecular identification of Nosema species in provinces of Fars, Chaharmahal and Bakhtiari and Isfahan (Southwestern Iran). Asian Pac J Trop Biomed 7: 10-13.

BECNEL JJ, JEYAPRAKASH A, HOY MA AND SHAPIRO A. 2002. Morphological and molecular characterization of a new microsporidian species from the predatory mite Metaseiulus occidentalis (Nesbitt) (Acari, Phytoseiidae). J Invertebr Pathol 79: 163-172.

BIGLIARDI E AND SACCHI L. 2001. Cell biology and invasion of the microsporidia. Microbes Infect 3: 373-379.

BJØRNSON S. 2008. Natural enemies of mass-reared predatory mites (family Phytoseiidae) used for biological pest control. Exp Appl Acarol 46: 299-306.

BJØRNSON S AND KEDDIE B. 1999. Effects of Microsporidium phytoseiuli (Microsporidia) on the performance of the predatory mite, Phytoseiulus persimilis (Acari: Phytoseiidae). Biol Control 15: 153-161.

BJØRNSON S, STEELE T, HU Q, ELLIS B AND SAITO T. 2013. Ultrastructure and molecular characterization of the microsporidium, Nosema chrysoperlae sp. nov., from the green lacewing, Chrysoperla carnea (Stephens) (Neuroptera: Chrysopidae) used for biological pest control. J Invertebr Pathol 114: 53-60.

CANNING EU, CURRY A, CHENEY S, LAFRANCHITRISTEM NJ AND HAQUE MA. 1999. Vairimorpha imperfecta n.sp., a microsporidian exhibiting an abortive octosporous sporogony in Plutella xylostella L. (Lepidoptera: Yponomeutidae). Parasitology 119: 273286.

COOMBS NJ, GOUGH AC AND PRIMROSE JN. 1999. Optimisation of DNA and RNA extraction from archival formalin-fixed tissue. Nucleic Acids Res 27: 1-3.

CORRADI N AND KEELING PJ. 2009. Microsporidia: a journey through radical taxonomical revisions. Fungal Biol Rev 23: 1-8.

DEAN P, HIRT RP AND EMBLEY TM. 2016. Microsporidia: Why Make Nucleotides if You Can Steal Them? PLos Pathog 12: 1-13.

DUBUFFET A, SMITH JE, SOLTER L, PEROTTI MA, BRAIG HR AND DUNN M. 2013. Specific detection and localization of microsporidian parasites in invertebrate hosts by using in situ hybridization. Appl Environ Microbiol 79: 385-388.

EMSEN B, GUZMAN-NOVOA E, HAMIDUZZAMAN MM, ECCLES L, LACEY B, RUIZ-PÉREZ RA AND NASR M. 2016. Higher prevalence and levels of Nosema ceranae than Nosema apis infections in Canadian honey bee colonies. Parasitol Res 115: 175-181.

FONSECA APP, MARQUES EJ, TORRES JB, SILVA LM AND SIQUEIRA HAA. 2015. Lethal and sublethal effects of lufenuron on sugarcane borer Diatraea flavipennella and its parasitoid Cotesia flavipes. Ecotoxicology 24: 1869-1879.

GISDER S, MOCKEL N, LINDE A AND GENERSCH E. 2011. A cell culture model for Nosema ceranae and Nosema apis allows new insights into the life cycle of these important honey bee-pathogenic microsporidia. Environ Microbiol 13: 404-413.

GISDER S, SCHÜLER V, HORCHLER LL, GROTH D AND GENERSCH E. 2017. Long-term temporal trends of Nosema spp. infection prevalence in Northeast Germany: continuous spread of Nosema ceranae, an emerging pathogen of honey bees (Apis mellifera), but no general replacement of Nosema apis. Front Cell Infect Microbiol 7: $1-14$.

HIGES M ET AL. 2008. How natural infection by Nosema ceranae causes honeybee colony collapse. Environ Microbiol 10: 2659-2669.

HUANG WF, JIANG JH, CHEN YW AND WANG CH. 2007. A Nosema ceranae isolate from the honeybee Apis mellifera. Apidologie 38: 30-37.

HUELSENBECK JP AND RONQUIST F. 2001. MRBAYES: Bayesian inference of phylogenetic trees. Bioinformatics Applications Note 17: 754-755.

KERMANI N, ABU HASSAN ZA, SUHAIMI A, ABUZID I, ISMAIL NF, ATTIA M AND GHANI IA. 2014. Parasitism performance and fitness of Cotesia vestalis (Hymenoptera: Braconidae) infected with Nosema sp. (Microsporidia: Nosematidae): implications in integrated pest management Strategy. PLoS ONE 9: 1-9.

KING EG AND HARTLEY GG. 1985. Diatraea saccharalis. In: Singh P and Moore RF (Eds), Handbook of insect rearing. New York: Elsevier, p. 265-270.

KLEE J, TAY WT AND PAXTON RJ. 2006. Specific and sensitive detection of Nosema bombi (Microsporidia: Nosematidae) in bumble bees (Bombus spp.; Hymenoptera: Apidae) by PCR of partial rRNA gene sequences. J Invertebr Pathol 91: 98-104.

KU CT, WANG CY, TSAI YC, TZENG CC AND WANG CH. 2007. Phylogenetic analysis of two putative Nosema isolates from Cruciferous Lepidopteran pests in Taiwan. J Invertebr Pathol 95: 71-76.

KURZE C, DOSSELLI R, GRASSL J, LE Y, KRYGER P, BAER B AND MORITZ RFA. 2016a. Differential 
proteomics reveals novel insights into Nosema-honey bee interactions. Insect Biochem Mol Biol 79: 42-49.

KURZE C, MAYACK C, HIRCHE F, STANGL GI, LE CONTE Y, KRYGER P AND MORITZ RFA. 2016b. Nosema spp. infections cause no energetic stress in tolerant honeybees. Parasitol Res 115: 2381-2388.

LIU H, DING S, QIN Q, TANG J, LIU LAND PENG H. 2015. Morphological and phylogenetic analysis of Nosema sp. HR (Microsporidia;Nosematidae): a new microsporidian pathogen of Histia rhodope Cramer (Lepidoptera; Zygaenidae ). Parasitol Res 114: 983-988.

MORSY K, BASHTAR AR, ABDEL-GHAFFAR F AND ALQURAISHY S. 2013. Morphological and phylogenetic description of a new xenoma-inducing microsporidian, Microsporidium aurata nov. sp., parasite of the gilthead seabream Sparus aurata from the Red Sea. Parasitol Res 112: 3905-3915.

PARON MR AND BERTI-FILHO E. 2000. Capacidade reprodutiva de Trichospilus diatraeae (Hymenoptera: Eulophidae) em pupas de diferentes hospedeiros (Lepidoptera). Sci Agric (Piracicaba, Braz.) 57: 355-358.

PARRA JRP, BOTELHO PSM, CORRÊA-FERREIRA BS AND BENTO JMS. 2002. Controle biológico: uma visão inter e multidisciplinar. In: Parra JRP, Botelho PSM, Correa-Ferreira BS and Bento JRP (Eds), Controle biológico no Brasil: parasitoides e predadores, São Paulo: Manole, p. 125-137.

PEREIRA FF, ZANUNCIO JC, OLIVEIRA HN, GRANCE ELV, PASTORI PL AND GAVA-OLIVEIRA MD. 2011. Thermal requirements and estimate number of generations of Palmistichus elaeisis (Hymenoptera: Eulophidae) in different Eucalyptus plantations regions. Braz J Biol 71: 431-436.

RETSCHNIG G, WILLIAMS GR, SCHNEEBERGER AAND NEUMANN P. 2017. Cold ambient temperature promotes Nosema spp. intensity in honey bees (Apis mellifera). Insects 8: 1-12.

RODRIGUES MAT, PEREIRA FF, KASSAB SO, PASTORI PL, GLAESER DF, OLIVEIRA HN DE AND ZANUNCIO
JC. 2013. Thermal requirements and generation estimates of Trichospilus diatraeae (Hymenoptera: Eulophidae) in sugarcane producing regions of Brazil. Florida Entomol 96: 154-159.

SIMÕES RA, FELICIANO JR, SOLTER LF AND DELALIBERA I. 2015. Impacts of Nosema sp. (Microsporidia: Nosematidae) on the sugarcane borer, Diatraea saccharalis (Lepidoptera: Crambidae). J Invertebr Pathol 129: 7-12.

SIMÕES RA, REIS LG, BENTO JMS, SOLTER LF AND DELALIBERA I. 2012. Biological and behavioral parameters of the parasitoid Cotesia flavipes (Hymenoptera: Braconidae) are altered by the pathogen Nosema sp. (Microsporidia: Nosematidae). Biol Control 63: 164-171.

TAY WT, O'MAHONY EM AND PAXTON RJ. 2005. Complete rRNA gene sequences reveal that the microsporidium Nosema bombi infects diverse bumblebee (Bombus spp.) hosts and contains multiple polymorphic sites. J Eukaryot Microbiol 52: 505-513.

TSAI SJ, LO CF, SOICHI Y AND WANG CH. 2003. The characterization of microsporidian isolates (Nosematidae: Nosema) from five important lepidopteran pests in Taiwan. J Invertebr Pathol 83: 51-59.

VINSON SB AND IWANTCH GF. 1980. Host suitability for insect parasitoids. Annu Rev Entomol 25: 397-419.

WALSH PS, METZGER DAAND HIGUCHI R. 1991. Chelex 100 as a medium for simple extraction of DNA for PCRbased typing from forensic material. BioTechniques 10: 506-513.

WEISS LM. 2001. Microsporidia 2001: Cincinnati. Eukaryot Microbiol 48: 47-49.

ZACHÉ B, WILCKEN CF, DACOSTA RR AND SOLIMAN EP. 2010. Trichospilus diatraeae Cherian \& Margabandhu, 1942 (Hymenoptera: Eulophidae), a new parasitoid of Melanolophia consimilaria (Lepidoptera: Geometridae). Phytoparasitica 38: 355-357. 